\title{
The Assessment on Environmental Value of Thermal Power in China
}

\author{
Xuebing Tang \\ School of Economics and Management, Huazhong Normal University, Wuhan 430079, China \\ E-mail: xuebingt@126.com
}

Received: January 6, 2012

Accepted: February 7, 2012 Published: March 1, 2012

doi:10.5430/bmr.v1n1p115

URL: http://dx.doi.org/10.5430/bmr.v1n1p115

The research was supported by 2010 Major Project Development Scheme in Central University Basic Research Fund in Huazhong Normal University "Regional economic policy in China: combinational goals, realizing path and dynamic evaluation" and 2009 Dangui Scheme in Huazhong Normal University" the implementation mechanism of the equalization of basic public services in Hubei" (09DG019).

\begin{abstract}
This paper preliminarily estimates environmental value of thermal power (EVTP) in China by forecasting the size of thermal power units in future. It was found that China's EVTP is huge, and will exceed 200 billion yuan in 2017, 300 billion yuan in 2020 and 500 billion yuan in 2029. Meanwhile, there are a large number of investment opportunities in environmental technology development and environmental protection equipment installation in thermal power. Therefore, China's huge EVTP lays a solid foundation to development fund of thermal power.
\end{abstract}

Keywords: Environmental Value of Thermal Power (EVTP), Assessment, Development Fund

\section{Introduction}

The significant sign of the conversion of industrial civilization to ecological civilization is the establishment of resource-saving and environment-friendly society. China's average annual economic growth rate has been $9.84 \%$ since 1978, which led to rising global economic status and surpassing Japan to become the world's second largest economy in 2010. However, the feature of extensive growth mode in China, which is called "high input, high consumption, high emission, difficult cycle, low efficiency", has not been fundamentally changed. All sorts of conflicts in real life make us come to know that Chinese economic development would not going to be sustainable if the extensive economic growth mode had been transformed and high consumption of resources cut back. "China's Sustainable Development Strategy Report" issued by Chinese Academy of Sciences published in 2009 proposed that the target of China's low-carbon economy in 2020 is to lower the energy consumption per unit GDP by $40 \%$ to $60 \%$ and carbon dioxide emissions per unit GDP by 50 percent.

In order to achieve this goal, the priority is optimizing structure of China's energy supply and controling of sewage capacity by administrative or economic ways. Thermal power is one of the major pollutants in China such as smoke, sulfur dioxide, $\mathrm{NO}_{\mathrm{X}}$, dust, slag, ash rushing water and carbon dioxide. It is difficult to change China's power supply structure which mainly by thermal power and necessary to strengthen emissions trading, establish environmental funds and other means to reduce environmental pollution of thermal power. However, as market players, stakeholders are concerned about an environmental issue most is how much environmental value of thermal power (EVTP) in China will be? This paper attempts to answer this question.

Environmental value is one of the core concepts of contemporary environmental science and regards the people and the environment as a unified system, which not only attaches importance to human survival and development interests, but also attaches importance to the environment's tolerance and support for human values, respects for the environment and for all existence value of all life $(\mathrm{Xu}, 2005)$. In particular, economic value of environmental protection industry is the key stimulus for technical and management innovation. Hu Xiulian (2005) pointed out that as China's sustained and rapid development of power industry, the pollutants caused by coal-fired power plants, such as sulfur dioxide, nitrogen oxides, carbon dioxide and other greenhouse gas emissions, have been always rising, which should be paid sufficient attention to. Bai Xuejie et al (2009) proved that environmental regulation can improve China's overall efficiency of thermal power industry and incentive effects of technological innovation by three-stage DEA method. Wang Bing et al (2010) found that unit capacity utilization, coal-fired efficiency and environmental constraints have a significant impact 
on technical efficiency by directional distance function, but the effect of the reform of China's electric power system on technical efficiency has not been made. Zhou Jianguo et al (2011) reveal that the overall efficiency of the thermal power industry in China showed upward trend after the first drop in recent years, and maintaining a relatively stable level of energy efficiency can improve soft power and energy efficiency of the thermal power industry. Zhang Bing et al (2010) using a general equilibrium analysis framework, found that the coal and electricity prices will significantly affect market price and performance in emissions trading; in present system of coal price, the rise of coal prices continuously will greatly reduce quota prices and market activity. Zhang Gexing et al (2011) found that the overall technical efficiency of China's power industry is very low and showed a parabola form opening down with time. Zhou Ying et al (2011) account carbon dioxide emissions of all of our coal-fired power and analyze spatial distribution of the thermal power business number, unit capacity, energy type, carbon dioxide emissions and so on, which is meaningful to further analysis EVTP.

However, above literatures do not estimate the value of China's EVTP and this paper attempts to fill this gap. By predicting development scale of China's thermal power in future, we can calculate EVTP in China. Thus, the thermal power of the power structure and the huge potential for the development of environmental opportunities for further development of China's thermal power industry, environmental protection fund lays a solid economic foundation. Therefore, China's huge EVTP and supply structure of thermal power lay a solid foundation to development fund of thermal power.

\section{Assessment on China's environmental conservation value of thermal power}

Since the reform and opening-up, China has achieved great success in economic growth and its GDP has been increased from 364.52 billion yuan in 1978 to 39.8 trillion yuan in 2010, up $9.84 \%$ average annual growth rate, which surpassed Japan and became the world's second largest economy(See Figure 1). However, China's rapid economic growth is based on the rapid growth of energy supply. As can be seen from Figure 1, China's primary energy consumption has increased from 10.3 million tons of coal in 1990 to 27.5 million tons of coal in 2009, an average annual growth rate of $5.25 \%$. In other words, average annual growth of $5.25 \%$ in China's energy consumption supported the growth of national economy of $9.8 \%$ annually. In addition, the share of the use of coal in total primary energy has been also rising from $74.2 \%$ in 1990 to $76.7 \%$ in 2009 and the output of coal production has expanded from 1.08 billion tons in 1990 to 29.73 million tons in 2009 , an average annual rate of $5.47 \%$. China's economy is highly dependent on coal resources, which made energy shortages become commonplace.

(insert Figure 1)

China's coal-dominated energy structure determines the thermal-power-dominated of power structure. Since reform and opening-up, power construction has remained large-scale size and national power generation capacity has increased from 1.3789 million kilowatts in 1990 to 9.6219 million kilowatts in 2010, percent average annual growth of 10.21. At the same time, thermal power installed capacity has went up from 1.0184 million kilowatts in 1990 to 7.0663 million kilowatts in 2010, an average annual increase of $10.26 \%$. It can be seen that China's thermal power installed capacity has occupied $3 / 4$ of the total installed capacity and its growth rate is higher than the total. National power generating capacity has ascend from 621.32 billion kwh in 1990 to 4.228 trillion kwh in 2010, an average annual increase of $9.8 \%$, of which thermal power generating capacity rising from 494.97 billion kwh in 1990 to 3.4145 trillion kwh in 2010 . Therefore, thermal power generating capacity has occupied more than $80 \%$ of the total and its average annual growth rate is $9.9 \%$. China's power generating and installed capacity has been ranked second in the world more than 15 years. Thermal power installed capacity and electricity generation is based on the rapid growth of coal supply. In 2009, power generating output of 6000 kilowatts and above the national coal (including coal gangue) and fuel thermal power accounted for $95.96 \%$ of total thermal generating capacity and national electricity demand for coal production accounted for more than 50\%. Expected China's economy is also likely to remain above $8 \%$ growth rate in the next 20 years, even if the thermal power ratio in the energy mix has declined, its dominant position may also be maintained a very long period of time.

(insert Table 1)

Average value(1.03) of elasticity of electricity consumption in 1990-2010 multiplied by the economic growth rate of China in the 20 years is average growth rate $(8.24 \%$ ) of generating capacity at the same time(in base of 2010). Further, to predict the amount of pollution produced by a variety of thermal power in the next 20 years and their environmental space by calculating the amount of generating capacity of thermal power by which is $80 \%, 75 \%$, or $70 \%$ times of the total, respectively. The amount of $\mathrm{CO}_{2}$ emissions are calculated as follows: Based on China's standard coal consumption $335 \mathrm{~g} / \mathrm{kWh}$ of thermal power of 6000 kilowatts and above(the carbon element in standard coal is $85 \%$ ), we can get the amount of $\mathrm{CO}_{2}$ emissions produced by a TWh electricity: 
$335 \mathrm{~g} \times 0.85 / 12 \times 44=1044.8$ grams $(1.0448 \mathrm{~kg})$

The amount of other pollutants produced by a TWh electricity can be calculated by the pollution factor of production made by Ministry of Environmental Protection. The amount of all kinds of pollutants generated by thermal power in China's next 20 years can be seen in table 2.

(insert Table 2)

According to the 2010 global equivalent price(13.6 euros, $€ 1$ is equal to 8.94 yuan terms, about 121.6 yuan) per ton $\mathrm{CO}_{2}$, auction price of emission rights trading ( 4,200 yuan)per ton $\mathrm{SO}_{2}$ in trading center of Shaanxi Province in June 2010, water price (2.3 yuan / ton) as national average in 2010, if reduced by $20 \%$, China's EVTP in the next 20 years is shown in Table 3. It can be seen that the EVTP of China in 2017 will exceed 200 billion yuan, 300 billion yuan in 2020 and 500 billion yuan in 2029. Moreover, with the rising emission price of water, $\mathrm{CO}_{2}$ and $\mathrm{SO}_{2}$, and increasing efforts of emission reduction, EVTP will rise further.

(insert Table 3)

\section{Assessment the value of environmental technology and equipment of thermal power in China}

In addition to the value produced by emissions trading of thermal power, there are a large number of investment opportunities with development of environmental technology and equipment installation in thermal power industry.

(1) Denitrification

Recently, according to new requirements, new large-scale coal-fired units in China have been running in a low- $\mathrm{NO}_{\mathrm{x}}$ combustion synchronous mode, and flue gas denitrification equipment has come to set up in environmentally sensitive regions. Low-nitrogen-transformation burners have been installed in a number of existing thermal power plants. By the end of 2008, there had been about 200 sets of thermal power plants (nearly 200 million kilowatts) installed flue gas denitrification, but nearly 500 million kilowatts thermal power units needed to install those equipments. Provided that control standards of thermal power denitrification set as follow: Firstly, all new and existing coal-fired power boiler which has been approved by environmental assessment documents during January 1st, 2004 to December 31st, 2011, should be equipped with flue gas denitrification device which make $\mathrm{NO}_{\mathrm{x}}$ emission density below $100 \mathrm{mg} / \mathrm{m}^{3}$; secondly, power boilers put into operation or approved by environmental assessment documents before December 31st, 2003 should make NOx emission density below $200 \mathrm{mg} / \mathrm{m}^{3}$, national accounts of NOx emissions by thermal power are going to be $8.65,2.5$ and 2.80 million tons in 2010,2015 and 2020 respectively.

We could estimate that by 2015 , flue gas denitrification capacity need to add will have reached 817 million kilowatts. if high-efficiency and low-nitrogen burners and SCR should be installed, more than 195 billion yuan investment in denitrification should increased in order to transform outdated unit $(\$ 280$ per kilowatt-denitrification equipment investment) and install new units ( $\$ 150$ per kilowatt-denitrification equipment investment). If thermal power unit runs 5000 hours yearly and operating costs of denitrification per kilowatt are $\$ 0.015$, operating costs in 2015 are going to up to 61.2 billion yuan. In 2020, flue gas denitrification capacity need to add will have reached 1.066 billion kilowatts, investment in denitrification 232.8 billion yuan and operating costs 80 billion yuan.

\section{(2) Desulfurization}

By the end of 2008, thermal power installed capacity with desulfurization facilities had reached 363 million kilowatts, accounting for $60.2 \%$ of all. The existing thermal power emission standards ask $\mathrm{SO}_{2}$ control limit for the range from $400 \mathrm{mg} / \mathrm{m}^{3}$ to $1200 \mathrm{mg} / \mathrm{m}^{3}$, but new standards require western low-sulfur coal-fired mine-mouth power plants to install flue gas desulfurization devices which reduce $\mathrm{SO}_{2}$ emission limits to $200 \mathrm{mg} / \mathrm{m}^{3}$.

In 2015, there will be 131 million kilowatts of thermal power units need to install a new flue gas desulfurization equipments. If all units install high-efficiency wet method (limestone-gypsum method) and desulfurization equipment investment in new units is $130 \$ / \mathrm{kw}$, whole investment will rise up to 17 billion yuan. If thermal power unit runs 5000 hours yearly and operating costs of desulfurization per kilowatt are $\$ 0.015$, operating costs in 2015 are going to up to 9.8 billion yuan and 28.6 billion yuan in 2020 .

(3) Control of particulate matter

China's current emission standard for power plants in the control of particulate matter is the range from 50 to $200 \mathrm{mg} / \mathrm{m}^{3}$, but below $50 \mathrm{mg} / \mathrm{m}^{3}$ in developed countries generally. The accounts of particulate matter emissions in 2007 are 259 tons. According to the current level, the accounts of particulate matter emissions will reach 2.54, 2.85 and 3.03 million tons in 20102015 and 2020, respectively.

By 2015, there will be 131 million kilowatts of thermal power units need to install a new flue particulate matter removal 
device. Therefore, the use of electrostatic precipitator and high-frequency power will invest about 880 million yuan only considering increased costs of high-frequency one. If installing bag filter, added investment will reach 13.1 billion yuan. The operating costs of the 600MW units, for example, is about 400 million yuan yearly if high-frequency power transformed or newly installing investment. To $300 \mathrm{MW}$ unit, operating costs of bag filter is 300 yuan per ton particulate matter.

\section{Summary}

Through analysis, we can draw the following conclusions:

First, by reducing emissions by $20 \%$, the next 20 years, China's environmental protection industry, thermal power is a huge value in 2017 exceeded 200 billion yuan in 2020 will exceed 300 billion yuan in 2029 will exceed 500 billion yuan. Moreover, with the price of water and carbon dioxide, sulfur dioxide emission prices, and emission reduction efforts increase, the environmental value of thermal power will rise further.

Second, the thermal power business of environmental technology development and environmental protection equipment installation also produced a large number of investment opportunities. Denitrification in 2020, need to add flue gas denitrification capacity of 1.066 billion kilowatts, totaling 232.8 billion yuan investment in denitrification, operating costs in 2020 to be 80 billion yuan / year; desulfurization, 2015, the new thermal power plant flue gas desulphurization operating costs to $\$ 9.8$ billion / year by 2020, a new thermal power plant FGD operating cost 28.6 billion / year. Dust, if the power of high-frequency transformation of existing units, the cost of transforming part is about 1.51 billion yuan.

Therefore, China's enormous environmental value of thermal power for the environmental protection industry of China's thermal power development fund lays a solid economic base.

\section{References}

An, Xianghua, Jiang, Jun. (2011). Status-quo and some suggestions on control of $\mathrm{CO}_{2}$ emission from the thermal power industry of China. Chinese Coal, Vol.1:108-110[in Chinese].

Bai, xuejie, Song, Ying. (2009). Environmental regulation, technology innovation and efficiency improvement of Chinese thermal Power industry. China industrial Economics, Vol.8:68-77[in Chinese].

Wang, Bing, Lu, Jinyong ,Chen, Ru. (2010). An Empirical Study on Technical Efficiency of China's Thermal Power Generation and Its Determinants under Environmental Constraint. Economic Review, Vol. 4:90-97[in Chinese].

Zhang, Bing, Wang, Ke, Bi, Jun. (2010). The impact of coal and electricity markets on the performance of sulfur dioxide emission trading markets of thermal power industry. China Environmental Science, Vol. 30(3): 416 419[in Chinese].

Zhang, Gexing, Xia, Dawe, Ownership Structure. (2011). Environment Regulation and Efficiency of Chinese Power Generation Industry-Stochastic Frontier Production Function Analysis Based on Provincial Panel Data During 2003-2009. China industrial Economics, Vol. 6:130-140[in Chinese].

Zhou, Jianguo, Wang, Yingxue, Liang, Huaitao, Li Bin. (2011). Total Factor Energy Efficiency Research on Chinese Thermal Power Industry Considering Environmental Resources. East China Electric Power, Vol. 6:875-879[in Chinese].

Zhou, Ying, Cai, Bofeng, Liu, Lancui, Cao, Dong. (2011). Study on spatial distribution of $\mathrm{CO}_{2}$ emission from thermal. Thermal Power Generation, Vol.10:1-3[in Chinese]. 
Table 1. China's power generation capacity and lectricity generation since 1990

\begin{tabular}{|l|l|l|l|l|l|l|l|l|}
\hline Year & $\begin{array}{c}\text { power generation } \\
\text { equipment capacity } \\
\text { / GW }\end{array}$ & $\begin{array}{c}\text { Hydro } \\
\text { power }\end{array}$ & $\begin{array}{c}\text { thermal } \\
\text { power } \\
\text { power }\end{array}$ & $\begin{array}{c}\text { generating } \\
\text { capacity / TWh }\end{array}$ & $\begin{array}{c}\text { Hydro } \\
\text { power }\end{array}$ & $\begin{array}{c}\text { thermal } \\
\text { power }\end{array}$ & $\begin{array}{c}\text { nuclear } \\
\text { power }\end{array}$ \\
\hline 1990 & 137.89 & 36.05 & 101.84 & & 621.32 & 126.35 & 494.97 & \\
\hline 1995 & 217.22 & 52.18 & 162.94 & 2.1 & 1006.95 & 186.77 & 807.34 & 12.83 \\
\hline 2000 & 319.32 & 79.35 & 237.54 & 2.1 & 1386.5 & 243.1 & 1107.9 & 16.7 \\
\hline 2005 & 517.48 & 117.39 & 391.37 & 6.84 & 2474.7 & 401 & 2018 & 52.3 \\
\hline 2006 & 623.7 & 130.29 & 483.82 & 6.85 & 2865.7 & 435.8 & 2369.6 & 54.8 \\
\hline 2007 & 718.22 & 148.23 & 556.07 & 8.85 & 3281.6 & 485.3 & 2723.3 & 62.9 \\
\hline 2008 & 792.73 & 172.6 & 602.86 & 9.08 & 3451.01 & 565.5 & 2802.9 & 69.2 \\
\hline 2009 & 874.1 & 196.29 & 651.07 & 9.08 & 3681.19 & 571.7 & 3011.7 & 70.1 \\
2010 & 962.19 & 213.4 & 706.63 & 10.82 & 4228.02 & 686.3 & 3414.5 & 76.8 \\
\hline
\end{tabular}

Source: National Bureau of Statistics; China Electricity Council.

Table 2. The amount of all kinds of pollutants generated by thermal power in China's next 20 years

\begin{tabular}{|c|c|c|c|c|c|c|c|c|c|}
\hline \multirow[b]{2}{*}{ Year } & \multirow[b]{2}{*}{$\begin{array}{l}\text { amount } \\
\text { of power } \\
\text { (twh) }\end{array}$} & \multirow[b]{2}{*}{$\begin{array}{l}\text { amount of } \\
\text { thermal } \\
\text { power(twh) }\end{array}$} & \multirow{2}{*}{$\begin{array}{l}\text { amount of } \\
\text { coal } \\
\text { consumption } \\
\text { (One hundred } \\
\text { tons ) }\end{array}$} & \multicolumn{6}{|c|}{ The amount of all kinds of pollutants(One hundred tons) } \\
\hline & & & & $\mathrm{CO}_{2}$ & $\mathrm{SO}_{2}$ & dust & pink cinder & slurry & $\begin{array}{l}\text { washed ash } \\
\text { water(slurry) }\end{array}$ \\
\hline 2010 & 4228.02 & 3414.52 & 11.44 & 35.67 & 0.38 & 5.25 & 5.01 & 0.58 & 28 \\
\hline 2011 & 4576.41 & 3432.31 & 11.5 & 35.86 & 0.38 & 5.28 & 5.04 & 0.59 & 28.14 \\
\hline 2012 & 4953.5 & 3715.13 & 12.45 & 38.82 & 0.41 & 5.71 & 5.45 & 0.63 & 30.46 \\
\hline 2013 & 5361.67 & 4021.26 & 13.47 & 42.01 & 0.45 & 6.18 & 5.9 & 0.69 & 32.97 \\
\hline 2014 & 5803.48 & 4352.61 & 14.58 & 45.48 & 0.49 & 6.69 & 6.39 & 0.74 & 35.69 \\
\hline 2015 & 6281.68 & 4711.26 & 15.78 & 49.22 & 0.53 & 7.24 & 6.92 & 0.8 & 38.63 \\
\hline 2016 & 6799.29 & 5099.47 & 17.08 & 53.28 & 0.57 & 7.84 & 7.49 & 0.87 & 41.82 \\
\hline 2017 & 7359.55 & 5519.67 & 18.49 & 57.67 & 0.62 & 8.48 & 8.1 & 0.94 & 45.26 \\
\hline 2018 & 7965.98 & 5974.49 & 20.01 & 62.42 & 0.67 & 9.18 & 8.77 & 1.02 & 48.99 \\
\hline 2019 & 8622.38 & 6466.78 & 21.66 & 67.56 & 0.72 & 9.94 & 9.49 & 1.1 & 53.03 \\
\hline 2020 & 9332.86 & 6999.65 & 23.45 & 73.13 & 0.78 & 10.76 & 10.28 & 1.2 & 57.4 \\
\hline 2021 & 10101.89 & 7576.42 & 25.38 & 79.16 & 0.85 & 11.65 & 11.12 & 1.29 & 62.13 \\
\hline 2022 & 10934.29 & 8200.71 & 27.47 & 85.68 & 0.92 & 12.61 & 12.04 & 1.4 & 67.25 \\
\hline 2023 & 11835.27 & 8876.45 & 29.74 & 92.74 & 0.99 & 13.64 & 13.03 & 1.52 & 72.79 \\
\hline 2024 & 12810.5 & 9607.87 & 32.19 & 100.38 & 1.07 & 14.77 & 14.11 & 1.64 & 78.78 \\
\hline 2025 & 13866.08 & 10399.56 & 34.84 & 108.65 & 1.16 & 15.99 & 15.27 & 1.78 & 85.28 \\
\hline 2026 & 15008.65 & 11256.49 & 37.71 & 117.61 & 1.26 & 17.3 & 16.53 & 1.92 & 92.3 \\
\hline 2027 & 16245.36 & 12184.02 & 40.82 & 127.3 & 1.36 & 18.73 & 17.89 & 2.08 & 99.91 \\
\hline 2028 & 17583.98 & 13187.98 & 44.18 & 137.79 & 1.47 & 20.27 & 19.36 & 2.25 & 108.14 \\
\hline 2029 & 19032.9 & 14274.67 & 47.82 & 149.14 & 1.59 & 21.94 & 20.96 & 2.44 & 117.05 \\
\hline 2030 & 20601.21 & 15450.91 & 51.76 & 161.43 & 1.72 & 23.75 & 22.69 & 2.64 & 126.7 \\
\hline
\end{tabular}


Table 3. China's EVTP in the next 20 years (calculated by $20 \%$ of reduction)

\begin{tabular}{|c|c|c|c|c|c|c|c|c|c|}
\hline Year & $\mathrm{CO}_{2}$ & $\mathrm{SO}_{2}$ & water & $\begin{array}{c}\text { total } \\
\text { value }\end{array}$ & Year & $\mathrm{CO}_{2}$ & $\mathrm{SO}_{2}$ & water & $\begin{array}{c}\text { total } \\
\text { value }\end{array}$ \\
\hline 2010 & 867.6 & 320.1 & 64.4 & 1252.1 & 2021 & 1925.1 & 710.2 & 142.9 & 2778.3 \\
\hline 2011 & 872.1 & 321.8 & 64.7 & 1258.6 & 2022 & 2083.8 & 768.8 & 154.7 & 3007.2 \\
\hline 2012 & 944 & 348.3 & 70.1 & 1362.3 & 2023 & 2255.5 & 832.1 & 167.4 & 3255 \\
\hline 2013 & 1021.8 & 377 & 75.8 & 1474.6 & 2024 & 2441.3 & 900.7 & 181.2 & 3523.2 \\
\hline 2014 & 1106 & 408 & 82.1 & 1596.1 & 2025 & 2642.5 & 974.9 & 196.1 & 3813.5 \\
\hline 2015 & 1197.1 & 441.7 & 88.9 & 1727.6 & 2026 & 2860.2 & 1055.2 & 212.3 & 4127.7 \\
\hline 2016 & 1295.8 & 478 & 96.2 & 1870 & 2027 & 3095.9 & 1142.2 & 229.8 & 4467.9 \\
\hline 2017 & 1402.5 & 517.4 & 104.1 & 2024.1 & 2028 & 3351 & 1236.3 & 248.7 & 4836 \\
\hline 2018 & 1518.1 & 560.1 & 112.7 & 2190.8 & 2029 & 3627.1 & 1338.2 & 269.2 & 5234.5 \\
\hline 2019 & 1643.2 & 606.2 & 122 & 2371.4 & 2030 & 3926 & 1448.4 & 291.4 & 5665.8 \\
\hline 2020 & 1778.6 & 656.2 & 132 & 2566.8 & & & & & \\
\hline
\end{tabular}

Description: Calculated by the amount of pollutants in Table 2 .

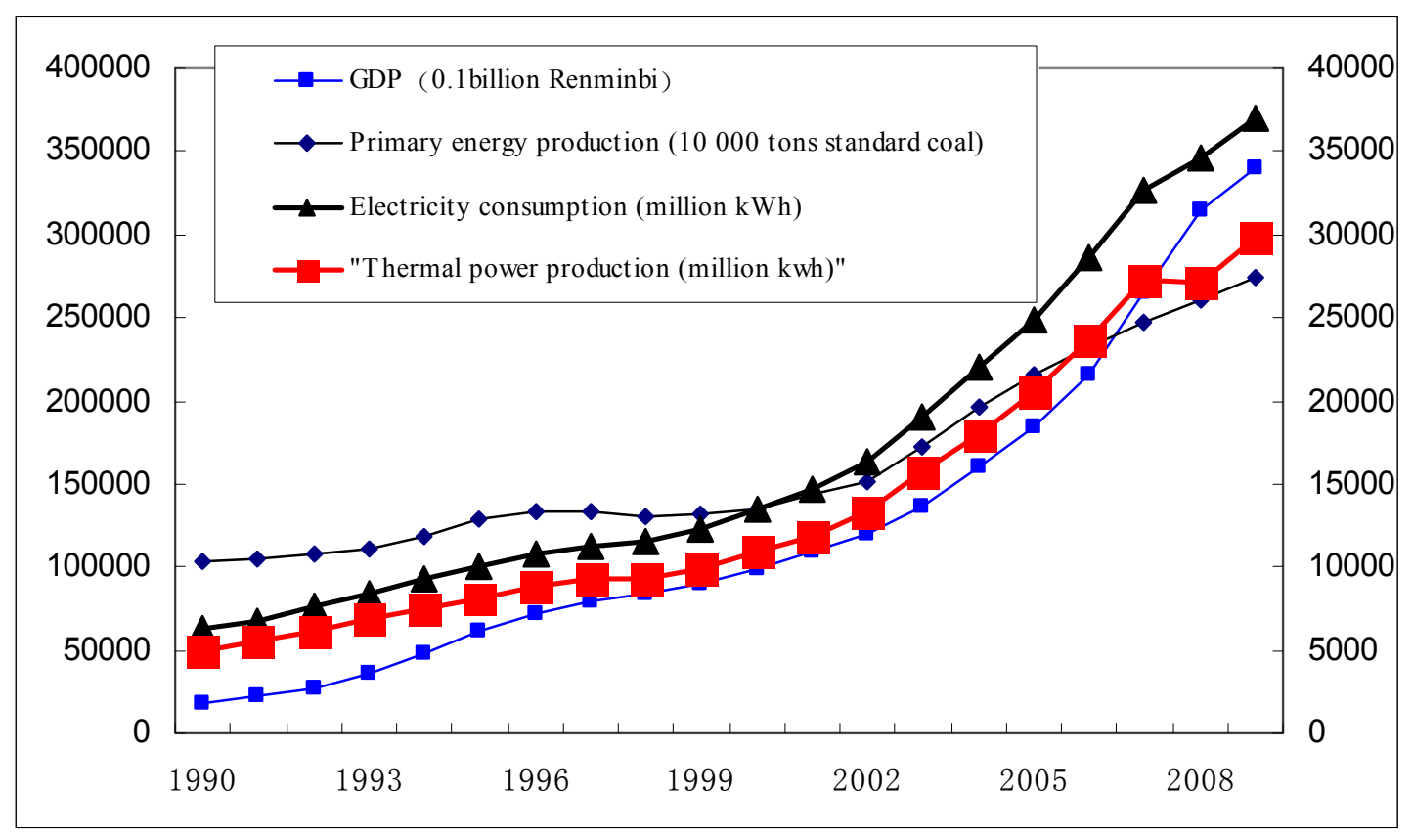

Figure 1. China's energy production and thermal power production (1990-2009)

Source: National Bureau of Statistics; China Electricity Council 